\title{
Identification of Industry Needs and Development of Professional Skills in Students of Horticulture
}

\author{
Brian J. Pearson ${ }^{1,3,5}$ and Kimberly Moore ${ }^{2,4}$
}

ADDITIONAL INDEX WORDS. soft skills, employment, career, teaching, industry

SUMMARY. Increased global trade coupled with diversified employment opportunities demand college graduates possessing well-developed professional skills. Recent survey results identified the importance of professional skills among candidates seeking employment, with communication being recognized as the most important skill or quality when selecting candidates. The ability to work within a team structure, solve complex problems, and organize and prioritize work also ranked high among industry employment needs. Despite a rigorous focus on disciplineoriented knowledge and skills, development of professional skills in students of horticulture may be overlooked or not fully developed. Teaching methods can be modified to incorporate development of professional skills and discipline-oriented knowledge to enhance student employment preparedness and directly address industry needs.

$\mathrm{E}$ xpanding global economic markets have generated increased need for college graduates possessing well-established career or professional skills (Hart Research Associates, 2015; World Economic Forum, 2014). Learning objectives within discipline-oriented college classes often focus on development of specific knowledge and technical skills. Development of professional skills may not be specifically targeted within course learning objectives, but these skills have been identified as the most important skills in hiring decisions of new college graduates (Crawford et al., 2011). Although horticultural employers often recognize the need for hands-on technical skills among graduates of plant science degree programs, students must also master an array of professional skills for career success. Poor understanding of employment needs coupled with learning objectives that do not adequately

\footnotetext{
This article was part of the workshop "Developing Soft Skills in Tomorrow's Leaders" held 10 Aug. 2016, during the ASHS Annual Conference, Atlanta GA, and sponsored by the ASHS Teaching Methods Working Group.

${ }^{1}$ Environmental Horticulture Department, University of Florida, Mid-Florida Research and Education Center, 2725 S. Binion Road, Apopka, FL 32703

${ }^{2}$ Environmental Horticulture Department, University of Florida, Fort Lauderdale Research and Education Center, 3205 College Avenue, Davie, FL 33314

${ }^{3}$ Assistant Professor

${ }^{4}$ Professor
}

${ }^{5}$ Corresponding author. E-mail: bpearson@ufl.edu. doi: 10.21273/HORTTECH03677-17 address professional skill development may produce graduates that are at a competitive disadvantage when seeking industry employment. The objectives of this article are 1) to identify discipline-oriented knowledge and professional skill needs of employers in college graduates and 2) to present instructional methodology and teaching tool implementation that simultaneously address development of discipline knowledge and professional skills in students of horticulture.

\section{What are professional skills?}

Postsecondary institutions of higher education often use an organizational hierarchy of colleges and departments to serve as disciplineoriented assemblies for the development of research, teaching, and extension programs. Courses originating from academic units are often discipline-oriented and rely on faculty to use programmatic expertise to develop course content. Although discipline-specific knowledge and skills are necessary for successful employment in horticulture, broad-based skills, often referred to as professional or soft skills, are also critical for career success. Employer surveys found professional skills to be lacking in college graduates (Crawford et al., 2011; Hart Research Associates, 2015; O'Brien, 1997; Ricker, 2014), thus suggesting a need for modification of the educational content to ensure these skills are acquired.
Professional skills can encompass various career-oriented proficiencies and have been defined to include interpersonal and intrapersonal communication, problem solving, critical thinking, teamwork, technology, and information literacy skills (Candy et al., 1994; Guthrie, 1994; Harvey, 1993; Mayer, 1992). When professional skills are taught separate from the discipline-specific content, they may not be regarded as essential or important for career success (Hattie et al., 1996). Hence, the inclusion of professional skills within disciplinespecific courses will allow students to develop these much-needed skills before entering the work force.

\section{What are the needs of the industry?}

It may often be difficult to ascertain needs for professional skills within the wide array of employment opportunities and career paths available to graduates of horticulture or plant science degree programs. Despite being long established as a major industry that employs over two million individuals (Hodges et al., 2015), hiring needs of the horticultural industry have not been specifically examined by members of the academic community. Although horticulture is a unique field of study and career choice, the hiring needs of the horticultural industry are similar to that of other industries.

Crawford et al. (2011) observed unique and interesting trends when reviewing results from a crossinstitutional survey that identified priorities in knowledge and skill development among 2669 students, 898 faculty, 4262 alumni, and 282 employers. The survey included student and faculty participants from 31 universities and at least one employer within each U.S. state, the District of Columbia, PR, and Guam. When skill type was surveyed using forced ranking to prioritize needs, students identified discipline knowledge, professional skills, and discipline technical skills as the most important skills for future career success. Similarly, faculty-ranked discipline knowledge, technical skills, and professional skills as the top perceived needs for future employment success. This difference may reflect discipline bias that likely exists between instructors and their 
students. Employers ranked professional skills as their top priority, followed by discipline technical skills and knowledge. The most desired professional skills by employers are communication, problem solving, self-management, and teamwork skills (Crawford et al., 2011). Employer needs identified in this survey are not limited to careers in private industry, but apply to all science-based nonacademic fields. In a similar survey of employment needs among 2138 hiring managers and human resources professionals, $77 \%$ stated professional skills were of equal importance as discipline knowledge and technical skills (Ricker, 2014). Moreover, 16\% of those surveyed reported professional skills as the most important proficiencies possessed by a new hire.

Institutions of higher education have been criticized for failing to develop necessary professional skills among graduates to meet advanced agricultural employment needs (Campbell, 1998; National Research Council, 2009). A survey conducted on behalf of the Association of American Colleges and Universities examined perceptions of career preparedness of college graduates from 613 students and 400 employers (Hart Research Associates, 2015). Similar to results reported by Ricker (2014), 85\% of employers identified professional skills as equal to or more important than discipline-oriented knowledge and skills. Although college graduates reported high levels of proficiency in professional skills, employers felt students were $\approx 2$-fold less proficient in these areas. Only $23 \%$ of employers felt recent college graduates possessed sufficient ability to apply professional knowledge. Survey results suggest a greater emphasis on development of professional skills is needed to meet industry employment needs. Failing to address industry's need for improved professional skills among graduates may contribute to the public perception that higher education is currently failing to develop critical skills necessary for advanced agricultural employment opportunities (Campbell, 1998; National Research Council, 2009).

Crawford et al. (2011) polled university faculty, students, alumni, and employers to identify whom is responsible for the development of professional skills in graduates. Survey results indicated that $17 \%$ of respondents felt it was the responsibility of the employer, whereas $28 \%$ felt it was the responsibility of academic institutions. The majority of respondents (55\%), however, felt development of professional skills in graduates was equally shared amongst industry and academia. Thus, graduates would be more prepared for industry employment if employment needs were identified and if industry and academia shared responsibility for the development of these desired skills in graduates.

\section{Can professional skill development be integrated into current learning objectives?}

Transfer of knowledge and skills within the classroom can occur using a diverse array of teaching methods (McKeachie, 1994). Many instructors have developed course objectives in their areas of specialty through perceived needs for discipline-oriented knowledge and skills without consideration of professional skill development (Bloom et al., 1956). When confronted with the need for improvement in student professional skills, instructors may develop learning objectives that target professional skills independent of discipline-oriented course content. However, this method lacks instructional effectiveness and perceived value associated with learning objectives (Hattie et al., 1996). Instead, professional skill development should be integrated into disciplineoriented content for it to be impactful to students and acknowledged as equally important for their career success. Cognitive learning theory and educational research suggest learning is most effectively attained when classroom materials and exercises closely resemble expected employment environments (Brown et al., 1989). Thus, teaching methods that integrate horticultural knowledge and professional skill development, and mimic workplace scenarios would directly address employment needs of industry.

Different teaching methods can be used to integrate discipline knowledge and professional skills for employment preparedness. For example, students could apply their knowledge to develop a mock product or horticultural technique; and each student could present their concept as a mock sales presentation of their product or technique for their peers to assess and grade (Silvester et al., 2002). This student-centered, peerto-peer teaching method incorporates comprehension, application, analysis, synthesis, and evaluation of information while focusing on the development of professional communication skills. Moreover, it provides a scenario similar to that encountered during employment, complete with performance incentive and reward. In addition, existing teaching methods and learning tools can be modified to incorporate a focus on professional skill development. Teaching methods that focus on teamwork, use of technology, and intra- and interpersonal skills aid in professional skill development and discipline aptitude to further prepare graduates for workplace entry (McKeachie, 1994).

Well-developed oral and written communication skills are among the top needs identified by employers (Crawford et al., 2011; Hart Research Associates, 2015). To help facilitate the development of these skills, students could research a selected or assigned topic and present a short presentation for their peers to assess. This teaching method is not limited to traditional, face-to-face courses, but can also be used in online, distancebased courses (Pearson and Moore, 2016). To implement this assignment online, the instructor could request students record a video or prepare a short narrated lecture on a given topic and have them upload their presentation to a course website. The assignment can be assigned to a student's peers for review and assessment. In addition to providing an opportunity to refine oral and written communication skills, this assignment helps facilitate peer-topeer learning opportunities that are often difficult to implement in online courses.

Service learning is a teaching method that integrates community service with discipline-oriented content (King, 2004). Service learning often involves hands-on, group learning exercises that facilitate and require oral communication with community members. These experiences provide students with opportunities to refine and develop communication and 
teamwork skills. Service learning activities can be integrated into horticultural studies through landscape design and restoration activities (Davis, 1999; VanDerZanden, 2015). In addition to fostering enhancement of communication and teamwork skills, service learning allows students to learn in an environment closely resembling an employment scenario and thus serves as a highly effective setting for professional skill development (Brown et al., 1989).

\section{Conclusion}

Demand for college graduates possessing well-developed professional skills has resulted from expansion and diversification of global economic markets. Surveys indicate recent graduates do not possess significant professional skill proficiency to meet industry employment needs. The ability to communicate effectively, work within a team structure, solve complex problems, and organize and prioritize ranked high among industry needs. Despite a rigorous focus on discipline-oriented knowledge and skills, development of professional skills in horticulture students may be overlooked or not fully developed. Enhancement of professional skill proficiency in graduates of horticulture will better prepare them for workplace entry. However, existing teaching methods and learning objectives can be modified to incorporate development of professional skills and discipline-oriented knowledge to enhance student employment preparedness and directly address needs of industry.

\section{Literature cited}

Bloom, B., M. Engelhart, E. Furst, W. Hill, and D. Krathwohl. 1956. Taxonomy of educational objectives: The classification of educational goals. Handbook I: Cognitive domain. David McKay, New York, NY.
Brown, J., A. Collins, and P. Duguid. 1989. Situated cognition and the culture of learning. Educ. Res. 18:32-42.

Campbell, J.R. 1998. Reclaming a lost heritage: Land-grant and other higher education initiatives for the twenty-first century. Michigan State Univ. Press, East Lansing, MI.

Candy, P., G. Crebert, and J. O'Leary. 1994. Developing lifelong learners through undergraduate education. Natl. Board Employment Educ. Training, Canberra, Australia.

Crawford, P., S. Lang, W. Fink, R. Dalton, and L. Fielitz. 2011. Comparitive analysis of soft skills: What is important for new graduates? 5 May 2017. <https://ag. purdue.edu/oap/career/Documents/ $2012 \% 20$ S oft $\% 20$ Skills $\% 20$ Survey $\%$ 202011\%20Crawford\%20Lang\%20Fink\% 20Dalton\%20Fielitz.pdf>.

Davis, G. 1999. Landscape design courses provide opportunities for service learning. North Amer. Colleges Teachers Agr. 43:23-25.

Guthrie, B. 1994. Graduate labour market survey. Austral. Govt. Publ. Service, Canberra, Australia.

Hart Research Associates. 2015. Falling short? College learning and career success. 5 May 2017. <https://www.aacu.org/ sites / default / files / files / LEAP / 2015 employerstudentsurvey.pdf $>$.

Harvey, L. 1993. Proceedings of the second QHE 24-hour seminar: Employer views of higher education. QHE Project, Coventry, UK.

Hattie, J., J. Biggs, and N. Purdie. 1996. Effects of learning skills interventions on student learning: A meta-analysis. Rev. Educ. Res. 66:99-136.

Hodges, A.W., C.R. Hall, M.A. Palma, and H. Khachatryan. 2015. Economic contributions of the green industry in the United States in 2013. HortTechnology 25:805-814.

King, J.T. 2004. Service-learning as a site for critical pedagogy: A case of collaboration, caring, and defamiliarization across borders. J. Experiential Educ. 26:121137.

Mayer, E. 1992. Key competencies. Austral. Educ. Council Ministers Vocational Educ. Employment Training, Canberra, Australia.

McKeachie, W.J. 1994. Teaching tips: Strategies, research, and theory for college and university teachers. Houghton Mifflin, Boston, MA.

National Research Council. 2009. Transforming agricultural education for a changing world. Natl. Acad. Press, Washington, DC.

O'Brien, T. 1997. Life after college: Employment, further education, lifestyle for recent grads. Amer. Assn. Higher Educ., Washington, DC.

Pearson, B.J. and K.A. Moore. 2016. Enhancement of student engagement and interaction in online courses through implementation of a scholar-ignite program. North Amer. Colleges Teachers Agr. 60(1):30 (abstr.).

Ricker, S. 2014. The skill set more than $3 / 4$ of employers want. 23 Jan. 2017. <http:// advice.careerbuilder.com/posts/the-skillset-more-than-of-employers-want>

Silvester, K.J., J.F. Durgee, C.M. McDermott, and R.W. Veryzer. 2002. Perspective: Integrated market-immersion approach to teaching new product development in technologically-oriented teams. J. Prod. Innov. Mgt. 19:18-31.

VanDerZanden, A. 2015. Rebuilding historic Irish gardens one peat brick at a time. HortScience 50(9):S274 (abstr.).

World Economic Forum. 2014. Matching skills and labour market needs: Building social partnerships for better skills and better jobs. 5 May 2017. <http://www3.weforum.org/docs/ GAC/2014/WEF_GAC_Employment_ MatchingSkillsLabourMarket_Report_ 2014.pdf $>$. 